\title{
Author Correction: Enhanced Approaches to the Identification, Evaluation, and Control of Impurities
}

\author{
Matt E. Popkin ${ }^{1} \cdot$ Phil J. Borman ${ }^{1} \cdot$ Batool Ahmed Omer ${ }^{1} \cdot$ Adam Looker $^{2} \cdot$ Jeffrey M. Kallemeyn ${ }^{3}$
}

Published online: 11 March 2019

(C) Springer Science+Business Media, LLC, part of Springer Nature 2019

\section{Author Correction: Journal of Pharmaceutical Innovation https://doi.org/10.1007/s12247-018-9363-8}

The original version of this article unfortunately contained a mistake. The authors in the author group were listed incorrectly. The correct author group of this article is "Matt E. Popkin • Phil J. Borman • Batool Ahmed Omer • Adam Looker • Jeffrey M. Kallemeyn.”

The author apologizes for this oversight and for any confusion it may have caused.

The original article has been corrected.

Publisher's Note Springer Nature remains neutral with regard to jurisdictional claims in published maps and institutional affiliations.

The online version of the original article can be found at https://doi.org/ $10.1007 / \mathrm{s} 12247-018-9363-8$

Matt E. Popkin

matt.e.popkin@gsk.com

1 Product Development and Supply, GlaxoSmithKline Ltd, Gunnels Wood Road, Stevenage, Herts SG1 2NY, UK

2 Process Chemistry, Vertex Pharmaceuticals Inc., 50, Northern Ave., Boston, MA 02210, USA

3 AbbVie Inc., 1 N. Waukegan Rd., North Chicago, IL 60064, USA 